CITE as:

Regilme S.S.F., Beller B. (2020) Security State. In: Romaniuk S., Thapa M., Marton

P. (eds) The Palgrave Encyclopedia of Global Security Studies. Palgrave Macmillan, Cham

\title{
Security State
}

\section{Security State}

Salvador Santino F. Regilme, Jr. and Beate Beller History and International Studies, Institute for History, Leiden University, Leiden, The Netherlands

\section{Kevwords}

State $\cdot$ Security $\cdot$ Violence $\cdot$ Securitization $\cdot$ Coercion

\section{Introduction}

Security state refers to the mode of the state, particularly when it wholeheartedly posits the importance of defending and maintaining its ontological existence from perceived threats within and beyond its claimed territorial as well as substantive spheres of influence. A security state ensures the intensification and enhancement of its instruments of political violence, repression, and coercion as a core strategic response to an overall perception of increasing threat within its domestic territory and from outside its borders. A security state places all other non-militaristic policy concerns - including economic development, social services, public health, etc. - under the overarching goal of military security. On the other hand, absent such a perceived existential threat, a non-security state may proceed in its regular state of affairs, particularly by treating each non-militaristic policy concerns as they are, particularly by not employing violent and coercive modes of control in order to provide such public goods. Domestically, a security state may frame a particular group of individuals - for example, users and traffickers of illegal drugs - as an existential threat to state and public security. In so doing, while a non-security state, in principle, may treat the proliferation of illegal drug use as a public health menace that primarily requires non-militaristic approaches, a security state, meanwhile, may employ police and military forces to implement an intensified and violent state crackdown of drug users and traffickers. Transnationally, the 9/11 attacks and the policy responses of American leaders since then facilitated the expansion of the security state, which now includes a vast security apparatus responsible for surveillance, intelligence gathering, and counterterror operations - all of which operate within and beyond United States borders (Priest and Arkin 2011).

\section{Defining State and Security}

The academic discipline of security studies deals with the fundamental questions of security and organized violence, with states as the traditional holders of legitimized form of violence in many political communities worldwide. The role of the state as the object as well as the provider of security has thereby been one of the central debates in the field. For traditional security scholars, the field 
of security studies focuses mainly on the realm of interstate war and the use of military force abroad. Consequently, the main concentration of the field was on the deployment of military forces outside the state for purposes of expansionism or military defense (Mabee 2003). The attention to nontraditional security issues and threats has reshaped the field as a whole and provided new perspectives and areas of inquiries. This alteration in the approach to security studies suggests that security is an important but only partial element in terms of state functions and responsibilities.

The conceptualization of security has seen a remarkable reorientation after the Cold War as the end of the bipolar world order gave rise to critical voices claiming that threats to national security go beyond the military sphere. Issues such as terrorism, international crime, or drug smuggling but likewise environmental degradation, climate change, epidemics, and the trafficking of humans might be considered as threats to a state's security. Notably, this change implies a transformation of the field regarding security as a broader, multiplex realm that involves not only states but also indi- viduals, groups, and networks. It has furthermore stimulated discussions of who is to be protected by security measures and who is to provide the security desired. Therefore, the diversification of security threats has enlarged the field of security studies and went hand in hand with an expanded notion of security referents.

This shift in the traditional agenda of security studies is crucial in understanding the emergence of the security state. This concept refers to a more extensive internal security agenda by the state exemplified by intensified patrolling, policing, surveillance, and militarization of the domestic sphere. Thus, while interstate war is diminishing, domestic state policing is argued to be on the rise. Regarding this development, Peter Andreas and Richard Price (2001) add that security concerns in a security state are moving from the previous focus on external warfighting with other states to an ongoing practice of internal crime fighting.

Lastly, the conceptualization of the state and the process of state making is an ongoing development closely related and determined by temporal, geographic, historical, and political factors.
Bryan Mabee (2003) criticizes that a historical understanding of the state fails to consider that its setup is subject to change and modification. Furthermore, there might arise a variety of different expectations and connotations regarding the state and state power as such. This is particularly relevant when state making is associated with a historicity of violence such as colonization or contentious in terms of its geographic orpolitical makeup. As with other concepts, there exists a certain difficulty to generalize about the security state as there remains a discrepancy in terms of the theoretical idea and its implementation in various differing political contexts.

\section{The Weberian State and the Provision of Security}

Max Weber's definition of the state places an emphasis on the "monopoly of the means of physical violence" within a "territorially demarcated area" (see Mann 1984). It is argued that this monopoly of violence stems from the state's capacity to provide protection to its citizenry. Further scholars on state making such as Michael Mann (1984) break down Weber's original definition into more differentiated elements. Not only the legitimate use of physical violence is central to the concept of the state but also its more encompassing institutional arrangements. Mann distinguishes between despotic and infrastructural powers of the state in which the former describes a situation in which a state elite acts in neglect of the demands of civil society. Infrastructural power, on the other hand, is connoted more positively with the state's ability to arbitrate social relations.

The twentieth century paved the way for the rise of the modern national security state, which must not be confused with the concept of the security state of the twenty-first century. In regard to this notion of national security, the state expands its power over its citizenry and thereby becomes the main entity of security provision. In return, the citizenry of the state is offered a variety of rights and protection as well as social and physical goods. This form of state organization is usually associated with the development of the 
welfare state. In terms of security studies, the idea of a national security state entails the defense of the state against external threats as well asensuring a satisfactory level of domestic well-being (Mabee 2003). However, there exists a trade-off between the provision of security by the state on the one hand and citizens' rights and freedoms on the other. The topic of how security provision by the state should look like and to which extent it is legitimate is open to debate and contestation.

The process of securitization leads to a situation in which issues usually not associated with security questions are now interpreted in this context (Regilme 2018). As a result, a trend evolves in which even ordinary members of society think and act more and more in terms of security considerations and public protection arguably at the cost of civil rights and liberties. This development produces a condition in which an increasingly more regulatory and controlling state is widely accepted as a necessary means to ensure public order and security (Zedner 2010). The curtailment of civil liberties and intrusion into the private sphere is facilitated by a sense of insecurity and fear spurred by international terrorism and perceived ascending crime rates. This also affects the domestic use of force by states whereby an increased militarization of public spaces can be observed.

A security state's deployment of coercion and influence also permeates the sphere of the civil society. It exceeds a Weberian notion of the "monopoly of legitimate violence" toward a state's deep penetration and management of vari- ous aspects of public life. The national security or welfare state that has emerged in the aftermath of the Second World War is now argued to be replaced by a more coercive form of state gover- nance. In view of this, the traditional paradigm of security becomes interwoven in various forms of domestic security strategies. A main characteristic of the security state is thus a shift in a state's organization of violence. Particularly, security states dramatically adopt a more extensive domes- tic security agenda involving an intensified penal system and police and military apparatus. In many ways, traditionally non-militaristic issues such as urban crimes, poverty, immigration, and border control are increasingly being subjected to the coercive agencies of the state, including the military and intelligence agencies - an outcome that ultimately expands the state's range of control over its citizens and subjects as well as enhances the capabilities for organized violence.

The 9/11 attacks in the United States not only motivated the dramatic expansion of the American security state but also intensified the interest of scholars in studying the causes and consequences of the expansion of security states worldwide, particularly when counterterrorism has been used to justify an increase in the level of state repression. This increase in state repression and ultimately the proliferation of security states in many polities worldwide profoundly undermined civil liberties and human rights. The emphasis on militaristic approaches to public policy illustrates the paradigm of coercive and punitive governance, which also includes co-opting the justice system in ways that they systematically and unduly punish individuals and groups deemed as security threats (Hallsworth and Lea 2011).

\section{The National and Transnational Dimensions of the Security State}

A security state usually harnesses various instruments of violence and repressive policies in order to fight crime, terrorism, poverty, and other public policy issues. In a lot of ways, a security state places traditionally non-militaristic issues as part of an overarching counterterror or military security strategy. As criminal law theory suggests, a form of "enemy penology" emerges that privileges the pursuit of security against those deemed dangerous or persistently defiant. Part of this development includes the prospective punishment of suspects, disproportionate measures for the sake of security and a hoped-for deterrent effect, as well as the departure from conventional procedure protection. Such preemptive criminalization is based on suspicious activity or speech for which the most commonly referred examples are terrorist suspects (Zedner 2010). However, this method in criminal law commences to transcend other areas in which citizens are considered as 
presumptive enemies and become targets of containment and regulation. In that sense, the "enemy population" constitutes those who are deemed dangerous or irrelevant to the security state, including those engaged in criminal or antisocial behavior, drug addicts, the homeless, the unem- ployed individuals, as well as undocumented migrants.

The security state deploys an intensified surveillance system that is legitimized by a state of exception often following disruptive incidents such as terror attacks. Consequently, the entire population is subjected to intensified levels of control and policing. These interventions of the state in certain areas of public life are implemented with the help of intelligence services and surveillance technology. A state-led form of intensified social control over individuals and groups along with the deployment of punishment as a form of governance strategy highlights some of the most problematic aspects of the security state. The infringement of civil liberties and rights as an accepted outcome of the advancement of the security state questions the legitimacy of this form of state organization and the trade-off against security provision.

A culture of fear and marginalization makes the subjection of certain groups of society even more pronounced and likely. Members of ethnic and religious minorities as well as socially and economically disadvantaged groups are usually the ones most detrimentally affected by such form of disciplining and discrimination. A global trend of Islamophobia has been observed resting upon anti-Muslim stereotypes. Moreover, in the United States and elsewhere, people of color have been found to be disproportionately targeted by a more vigorous American penal system resulting in overcrowded prisons and shattered community structures (Alexander 2010). Similar to the concept of "enemy penology" in criminal law, this form of restrictive governance has been termed as "the policing of a suspect community" (Fekete 2016).

In terms of foreign policy, Andreas and Price (2001) argue that the security state has implications for the implementation of military operations abroad, particularly for the most powerful states such as the United States. The conceptual distinction between external and internalsecurity has been blurred: as techniques usually associated with domestic policing continue to be adopted in the external security strategies, while militaristic approaches from an external security paradigm begin to be deployed in domestic security management. Andreas and Price (2001, p. 45) stress that the military paradigm is introduced to national policing strategies and "the deployment of US armed forced abroad has also increasingly resembled policing rather than traditional soldiering," particularly in the war on drugs, whereby the American military became more heavily involved in international law enforcement operations.

The war on drugs has substantially contributed to the emergency of the security state in the United States, both on a domestic level as well as concerning their foreign policy with their southern neighboring countries (Andreas and Price 2001). The "tough on crime" rhetoric and the reproduction of societal problems of inequality have led to coercive and punitive forms of governance. The dramatic expansion of the penal state system constitutes a crucial feature of the American security state. The persistently high incarceration rates, particularly among African American and Hispanic communities, have led scholars to suggest that the American penal system has developed into a system of institutional and social control whose primary targets can be identified by race and ethnicity (Alexander 2010).

Another dimension of the security state has been found in the management and disciplining of impoverished and disadvantaged populations. Loï Wacquant (2009) argues that the security state's violent repression of the most destitute sections of society debunks the idea that the security state enables social cohesion and integration. He maintains that the security state seeks to achieve "relief not to the poor but from the poor resulting in a wide-reaching expulsion of this population group from public concern and space. The penalization and criminalization of poverty is enabled through the normalization of social insecurity and exclusion on the one hand, and the assumption that poverty stems from a lack of work ethic and personal responsibility on the 
other. Similarly, John Lea (2002) speaks of a "debilitated authoritarianism" in which the state fulfils new aspects of controlling and regulating particular groups, especially segments of society that do not seem to conform to or benefit the economically productive state. The role of the welfare system in the conservation of social order is therefore replaced with a rigorous punitive and controlling system that uses the police, courts, and prisons in fulfilling its mission.

\section{Conclusion}

In sum, the security state embodies a mode of institutionalized and intensified control, coercion, and violent regulation of marginalized groups through the state's instruments of political violence. The security state's employment of violent modes of control, repression, and coercion emerges from its self-perception that it is facing existential threat from an external enemy. In many cases, such a response to a perceived threat is likely to lead security state leaders to suspend constitutional guarantees on human rights and civil liberties; to reduce, if not totally eliminate, various forms of checks and balances between government branches; and to further empower the institutional prerogatives and scope of power of the executive government as well as the state's coercive agencies including military and police institutions.

\section{Cross-References}

Failed States

Legitimacy in Statebuilding

Securitization and Desecuritization
Small States

Societal Security

State-Centric Paradigm

State Legitimacy

Surveillance States

Traditional Security

\section{References}

Alexander, M. (2010). The new Jim Crow - Mass incarceration in the age of colorblindness. New York: The New Press.

Andreas,P.,\& Price, R. (2001). From war fighting to crime fighting: Transforming the American National Security State. International Studies Review, 3(3), 1-23.

Fekete, L. (2016). Anti-Muslim racism and the European security state. Race and Class, 46(1), 4-29.

Hallsworth, S., \& Lea, J. (2011). Reconstructing leviathan: Emerging contours of the security state. Theoretical Criminology, 15(2), 141-157.

Lea, J. (2002). Crime and modernity - Continuities in left realist criminology. London: SAGE.

Mabee, B. (2003). Security studies and the "security state": Security provision in a historical context. International Relations, 17(2), 135-151.

Mann, M. (1984). The autonomous power of the state: Its origins, mechanisms and results. European Journal of Sociology, 25(2), 185-213.

Priest,D., \& Arkin,W.M.(2011). Top secret America: The rise of the new American security state - Dana Priest, William M. Arkin - Google books. New York: Little, Brown, and Company.

Regilme, S. S. F., Jr. (2018). Does US foreign aid undermine human rights? The "Thaksinification" of the war on terror discourses and the human rights crisis in Thailand, 2001 to 2006. Human Rights Review, 19(1), 73-95.

Wacquant, L. (2009). Punishing the poor: The neoliberal government of social insecurity. Durham: Duke University Press.

Zedner, L. (2010). Security, the state and the citizen: The changing architecture of crime control. New Criminal Law Review, 13(2), 379-403. 